\title{
SYNTHESIS OF SHORT-CUT DCF APPRAISAL AND SPREADSHEET ITERATION OF FREEHOLD RENTAL GROWTH RATES ACROSS SPECIFIC VALUATION EPOCHS
}

\author{
Joseph Obaje Ataguba \\ Department of Estate Management and Valuation \\ The Federal Polytechnic Idah, Kogi State Nigeria \\ e-mail: josephtgb81@gmail.com
}

\begin{abstract}
While the use of simple deterministic models to calculate rental value growth (RVGrowth) rate of reversionary freeholds across epochs prior to upward rent review appears illusive, literature evidence of the synthesis between short-cut DCF valuation and Solver tools in a spreadsheet does not constitute an exhaustive list of solutions. This study examined alternative spreadsheet and iteration tools that can determine RVGrowth rate of freehold investment properties across rent review epochs. With recourse to a hypothetical case of a freehold investment property, this experimental study identified the mathematical composition of RVGrowth in an explicit DCF framework, performed short-cut DCF Valuation and equivalent yield calculation at specific epochs prior to and including the full reversion; as well as using Goal Seek to calculate RVGrowth across all epochs prior to- and including the full reversion. Excel ${ }^{\circledR}$ Solver and Goal Seek, as well as the graphing/root-solving tool in Kyplot ${ }^{\circledR}$ were found to feasibly produce identical results for RVGrowth rate. This is among the limited studies that identified and researched the veracity of alternative tools for RVGrowth rate iteration. The value of this study is the awareness of alternative analytical tools avail freehold investors who desire knowledge of RVGrowth rate when making purchase-, hold-, and sales decisions.
\end{abstract}

Key words: scenario analysis, rental growth, freehold investment property, short-cut DCF, equivalent yield.

JEL Classification: C53, D46, R30.

Citation: Ataguba, J.O. (2021). Synthesis of short-cut DCF appraisal and spreadsheet iteration of freehold rental growth rates across specific valuation epochs. Real Estate Management and Valuation, 29(2), 52-70.

DOI: https://doi.org/10.2478/remav-2021-0013

\section{Introduction}

The prominence of expected rental growth rates in property appraisals can be traced to the advent of the reverse yield gap when gilt yields appeared to have risen above the initial yield of an investment property (Baum \& Crosby, 2008), and with attendant impacts on real capital and rental value growth over time (Fraser, 1993; Sayce et al., 2006; Wyatt, 2007). In response to the phenomenon of a reverse yield gap were the seminal works of McIntosh and Sykes (1983); McIntosh and Sykes (1985); and Sykes (1984) aimed at replacing the erstwhile implicit valuation of property investment with surrogates of growth explicit capital budgeting techniques, which was later christened as the ShortCut DCF valuation technique (Crosby, 1986; Crosby et al., 1997). Explicit DCF appraisals were further taken to an advanced level following the import of sophisticated analysis tools among which spreadsheets, scenario analysis, and simulations within the computer environment are included (Brown \& Matysiak, 2000; French, 2006a; Hargitay \& Yu, 1993; Hoesli et al., 2006; Li, 2000; Mackmin, 
1988; Meszek, 2013; Sayce et al., 2006), so that informed clients and their advisors might see a measure of transparency in the valuers' handling of property valuation and analysis.

Simplistic determination of implied rental growth rates were illustrated in seminal works of Baum et al. (2011), Fraser (1993), French (2006b), Isaac (1998) and Isaac (2002) among others. However, when a complex DCF valuation template is set up to calculate implied rental growth rate across each rent review epoch, it would not be feasible to apply simple algebraic equations. Therefore, the solution lies in the deployment of explicit DCF- and the equivalent yield valuation models and a synthesis of computerized iteration techniques. The short-cut DCF valuation model is structured to accommodate the projection of reversionary cash flows over the period to the next revision of market rent from the valuation date. When used as a tool for assessing the worth of an investment or to detect the degree of asset mispricing, the knowledge of the market price is crucial; and accounts for why it can be synthesized with the conventional equivalent yield valuation technique. If price, contract rent, market rent, and the number of years to the next rent review for a freehold investment property are known, then the equivalent yield can be determined. When these available parameters are deployed alongside the equated yield, then it is possible to determine the implied rental growth using software iterations as demonstrated in the seminal works of Brown and Matysiak (2000).

Brown and Matysiak (2000) illustrated three techniques capable of solving complex cases of freehold rental value growth rates across rent review epochs to include graphical method, Excel ${ }^{\circledR}$ Solver, and a customized Excel ${ }^{\circledR}$ Add-in called "RVGrowth". While applauding this unprecedented feat, it is not exhaustive to assert these as the only feasible techniques for the calculation of growth rate implied in a capitalization rate or required to achieve a specific price. This study aims to examine alternative spreadsheet and iteration tools that can possibly determine rental growth rate of freehold investment properties across rent review epochs. With recourse to a case of hypothetical freehold interest, specific objectives of this experimental study include identifying the mathematical composition of rental value growth (RVGrowth) rate within the explicit DCF framework; exploring available spreadsheet scenario analysis tools for the calculation of the expected rental growth rates upon commencement of a lease; verifying the spreadsheet-determined rental growth rate upon commencement of a lease using root-solving and graphing tools in select mathematical software; conducting short-cut DCF Valuation at specific epochs to the upward review of contract rent; calculating the equivalent yields at specific epochs to the upward review of contract rent; and exploring the use of Excel ${ }^{\mathbb{R}}$ Goal Seek to calculate expected rental growth across all rent review epochs.

It is envisaged that all techniques for rental growth iteration shall produce identical results, while availing analysts and investor with alternative analytical tools for making purchase-, hold-, and sales decisions.

\section{Literature review and analytical framework}

\subsection{Concept of rental value growth}

This sub-section reviewed the existing body of knowledge pertaining to the concept of rental value growth (RVGrowth) alongside its analytical constituents.

\subsubsection{Definition and significance in property investment appraisal}

Growth is quantitatively determined as the appreciation or a depreciation of a phenomenon. Investments including landed property produce two monetary measures that are subject to growth over time to include cash inflow (rental value) and capital value or price. The growth in the capital value of property may be perceived as capital gain or capital appreciation. Capital appreciation is the percentage increase in the capital value of a property between a preceding and succeeding date (Ifediora, 2005). On the other hand, rental growth was defined as the percentage increase in the cash inflow of a property between a preceding and succeeding date (Geltner \& de Neufville, 2018; Ifediora, 2005). It is worth noting that this notion of rental growth applies to the actual growth rate which Wyatt (2007) viewed to be different from the expected growth rate implied by the mathematical relationship between all risks yield, equated yield and the standard review period of the rent in question.

The emphasis in this study is that the "implied" rental growth rate, which is the geometric mean of the annual percentage change in rental values of rack-rented property investment taking into 
cognizance the rent review period and nominal yield which justifies the return achieved on the date of valuation or full disposal of the property (Brown \& Matysiak, 2000; Parsons, 2003; Udo, 2003). Surrogate for the implied rental growth rate is the geometric growth and decline models (Udo, 2003) which represent a constant percentage rate per compounding (annual) period (RICS, 1997), or the calculated geometric mean of the year-on-year change in rental value over a given period of time.

For properties valued part-way or transacted in between a rent review (valuation) epoch, the determination of implied rental growth is significant to the tracking of a match/mismatch between market expectation of rental growth and growth rates implied in a transaction (Brown \& Matysiak, 2000). Furthermore, it is used to project successive tranches of cash inflows to be discounted at the equated yield, in either the full or short-cut DCF valuation techniques (Isaac, 2002); inform borrowers on the amount by which projected property cash inflows exceed or fall short of the loan balance used to finance property acquisition (Geltner et al., 2010); gain useful insight into property income yields (Hoesli \& MacGregor, 2000) and track over-priced or under-priced properties (RICS, 1997).

\subsubsection{Rental value growth in reversionary freeholds}

The structure, timing, and receipt of cash flows in reversionary freeholds are collectively presented in dual forms; the first is the actual rent received as consideration arising from the contractual relationship between the headlessor and headlessee for a specific duration of years, whereas the second cash inflow is the anticipated market rent which the headlessor has the right to receive at full reversion in the future (Baum et al., 2011). In other words, the contract rent received is actually earned over a specific epoch, while the (risky) market rent is anticipated to be received in the future.

Across the epoch for the receipt of contract- and market rents is the phenomenon of rental growth, which is connected with the periodic revision of rent in response to average rates of inflation in the economy (Blackledge, 2009). The insertion of a clause for "upward" review of rent implies a positive rental growth, which is assumed to be continuously embedded in the periodic upward reviews of rent as inflation persists.

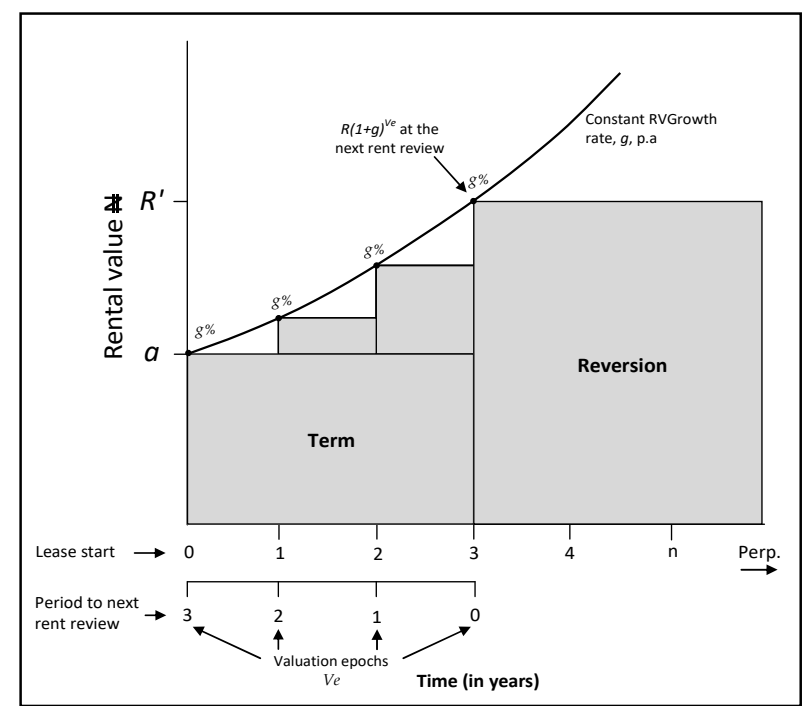

Fig. 1. Structure of term and reversion of Growth-bound freehold cash inflows. Source: own study.

With reference to the rent review/valuation epochs in Figure 1, the constant annual growth rate, $g \%$ is implied in the all risks yield used to value the freehold interest [See equations 4 and 13]. For instance, if the valuation of the freehold interest was done at the commencement of the lease (today), this implies that the fixed contract rent received today shall be due for upward review to the market rent [in say 3 years' time] such that the fixed income shall be appropriately discounted using the nominal (equated) yield (Baum \& MacGregor, 1992; Ifediora, 2005), while the revised market rent shall be appropriately discounted at the all risks yield, which contains the geometric mean of rental growth (RVGrowth) rate, $g \%$ and deferred for 3 years at the equated yield. A similar strategy shall apply to a scenario where contract rent is due for upward review across the other valuation epochs in Figure 1 but with the discounting of term rent- and the deferment of a reversionary income multiplier at the equated yield for the number of years to the next upward rent review. 


\subsubsection{Mathematical composition of rental value growth (RVGrowth) rate}

This sub-section attempts to unmask the mathematical composition of the RVGrowth rate using a system of inter-related equations involving growth explicit DCF appraisals:

For a fully let freehold investment property, the relationship between rent, $r_{0}$; capitalization rate (all risks yield), $k_{0}$ and price of the property, $P_{0}$ is expressed as:

$$
p_{o}=\frac{r_{o}}{k_{o}}
$$

In consonance with the seminal works of Adams et al. (1999); Baum and MacGregor (1992); Clayton et al. (2009); Doppeigieter and Rode (2002); Fraser (1993); McGough and Tsolacos (2001); and (Wyatt, 2013) importing the gordon's growth model into DCF appraisal of property investment, the incorporation of periodic rent reviews shall alter the original structure of equation 1 for the pricing of a reversionary freehold investment, where $g$ is the constant rental growth (RVGrowth) rate per annum; $e$, is the nominal discount rate (equated yield), and $t$ is the period between each rent review:

$$
p_{o}=\sum_{m=1}^{t} \frac{r_{o}}{(1+e)^{m}}+\sum_{m=1}^{t} \frac{r_{o}(1+g)^{t}}{(1+e)^{t+m}}+\sum_{m=1}^{t} \frac{r_{o}(1+g)^{2 t}}{(1+e)^{2 t+m}}+\ldots \ldots
$$

The geometric series in equation 2 is valid if $e>g$; and the sum of the series can be simplified as:

$$
p_{o}=\frac{r_{o}}{e-e\left(\frac{(1+g)^{t}-1}{(1+e)^{t}-1}\right)}
$$

Equating (1) and (3) results in the formula for the implicit all risks yield:

$$
k=e-e\left(\frac{(1+g)^{t}-1}{(1+e)^{t}-1}\right)
$$

In other words, all risks yield, $k$ is a function of the comparable sales price, equated yield, rental growth rates, and the period to the next upward rent review.

The implied rental growth rate (Equation 5) was derived from equation 4 as:

$$
g=\left(\frac{(e-k)(1+e)^{t}+k}{e}\right)^{1 / t}-1
$$

According to Brown and Matysiak (2000), an alternative structure for equation 5 deployed to calculate implied rental growth rate as understood by most valuers is:

$$
(1+g)^{t}=\frac{Y P \text { in Perp. } @ k-Y P \text { for tyears@e }}{Y P \text { in Perp. } @ k \times P V \text { in tyears@e }}
$$

Recalling that there is a relationship between $e$ and $g$, inflation risk free yield (IRFY) of a freehold investment property can be derived from equation 7 :

$$
\begin{gathered}
\frac{1}{1+i}=\frac{1+g}{1+e} \\
\text { as } i=\{(1+e) /(1+g)\}-1
\end{gathered}
$$

By substituting the right hand side of equation 5 in equation 8 , the inflation risk free yield, $i$ can be calculated using a first alternative formula:

$$
i=\left((1+e) \times\left(\frac{(e-k)(1+e)^{t}+k}{e}\right)^{-1 / t}\right)-1
$$


Similarly, substituting the right hand side of equation 6 in equation 8 would result in a second alternative model for the determination of inflation risk free yield, $i$ :

$$
i=\left((1+e) \times\left(\frac{Y \text { P in Perp. } @ k-Y P \text { for tyears@e } e}{Y \text { in Perp.@ } k \times P V \text { in tyears@e }}\right)^{-1 / t}\right)-1
$$

The use of the symbol "@" in equations 6 and 10 implies "at" in the financial maths parlance. Other texts tend to use the notation "|" in place of "@". For illustrative purpose, the years purchase in perpetuity at 5\% could be expressed in the financial maths parlance as "Y.P. in Perp. @ 5\%" or "Y.P. in Perp. $\mid 5 \% "$ ". Furthermore, Years purchase for 3 years at $18 \%$ could be expressed in the investment maths parlance as "Y.P. for 3 years @ 18\%" or "Y.P. for 3 years |18\%"; while the Present value of 1 in 3 years at 18\% is expressed in financial mathematics as "PV in 3 years @ 18\%" or "PV in 3 years|18\%".

Bringing to bear the relationship between the implied rental growth rate, $g$, inflations risk free yield, $i$ and the equated yield, $e$, equations 7 or 8 could still be used to derive the implied rental growth rate:

$$
g=\{(1+e) /(1+i)-1\}
$$

Therefore, equations 5, 6, and 11 indicate that the all risks yield of a freehold investment property is embedded in the RVGrowth rate alongside the equated yield and the standard rent review period.

Although Crosby et al. (1997) opined that implied rental growth rate is a function of the market capitalization rate and the nominal discount rate which likely underlie the strength of lease covenants, an observation and inference from equations 5, 6, and 11 is that the analytical constituents of implied rental growth depend on the structure and form of the chosen equation. Therefore, the four analytical constituents of RVGrowth rate for investment properties comprise the nominal discount rate (equated yield), rent review period, all risks yield and, where possible, the inflation risks free yield.

\subsection{The methodological differences between the full DCF- and short cut DCF}

Brown and Matysiak (2000) and IVSC (2003) reiterated that the DCF technique entails a measure of income capitalization. This income capitalization can be detailed as the discounting of tranches of cash inflows, hence the name discounted cash flow (DCF) technique. This section attempts to identify the methodological differences between the full DCF technique and short-cut DCF technique notwithstanding that they are capable of turning out identical results (Baum \& Shi Ming, 1985; Crosby, 1986; Crosby et al., 1997). The full DCF technique of property investment valuation originated from capital budgeting technique of net present value [NPV] determination. In the full DCF valuation of reversionary freehold interest, each tranche of tabulated periodic rent (cash inflow), excluding the contract rent, is inflated using the implied rental growth rate. The contract rent and tranches of projected reversionary rents are further discounted at the nominal rate of interest using the Years' Purchase- and Present Value functions. The last tranche of projected cash flow is capitalized at the all risks yield or capitalization rate (exit yield) in perpetuity and deferred using the nominal rate of interest in order to arrive at the exit value, so that the capital value of the reversionary freehold interest is found by adding up all discounted cash inflows and exit value.

The short-cut or modified DCF postulated exemplified by Baum and Crosby (2008), Crosby (1986), Crosby (1996), Crosby et al. (1997), and Isaac (1998), however, follows a rather simplified approach compared to the full DCF. The formula for the short-cut DCF valuation of reversionary freehold is illustrated as equation 14. In that equation, the capital value of the freehold interest, $P$, equals the sum of the capital value of contract rent and the capital value of the reversionary rent. The contract rent is multiplied by the YP at the nominal rate of interest for the duration of the term. However, the valuation of reversionary rent first commences with the projection of the market rent over the unexpired term of lease, capitalization of the projected rent at the all risks yield, and deferment of the capitalized rent at the equated yield. According to Crosby (1996), an alternative is to capitalize the market rent at the all risks yield and then defer the capitalized market rent using the net discount factor expressed as " $\frac{R}{k}\left(\frac{1+g}{1+e}\right)^{n} "$.

While both techniques have been adjudged to produce identical valuations, the preference of this study was tailored towards the short-cut DCF technique owing to its simplicity compared to the adoption of complex tabulations, rental projections, and separate stream of cash flow discounting. 


\subsection{Modelling Rental Value Growth using Short-cut DCF valuation}

The (explicit) short-cut DCF technique adopts a term and reversion valuation template as follows:

$$
P=\left(a\left(\frac{\left(1-(1+e)^{-n}\right)}{e}\right)\right)+\frac{R(1+g)^{n}}{e(1+e)^{n}}\left[\frac{\cdot\left((1+e)^{t}-1\right)}{(1+e)^{t}-(1+g)^{t}}\right]
$$

where $P=$ capital value of property, $a=$ rent passing, $R=$ Market rent, $n=$ number of years to the next rent review, $t=$ rent review period, $g=$ implied rental growth rate, and $e=$ equated yield.

An alternative to equation 4 for the all risks yield, $k$ can be drawn from equation 12 as:

$$
k=\frac{e\left((1+e)^{t}-(1+g)^{t}\right)}{\left((1+e)^{t}-1\right)}
$$

So that equation 12 can be written alternatively as:

$$
P=\left(\left(\frac{\left(1-(1+e)^{-n}\right)}{e}\right)\right)+\frac{R}{k}\left(\frac{1+g}{1+e}\right)^{n}
$$

By avoiding the notation for capitalization rate, equation 12 can be re-arranged to extract the implicit function from where the rental value growth rate can be iterated or calculated:

$$
\left(a\left(\frac{\left(1-(1+e)^{-n}\right)}{e}\right)\right)+\frac{R(1+g)^{n}}{e(1+e)^{n}}\left[\frac{\cdot\left((1+e)^{t}-1\right)}{(1+e)^{t}-(1+g)^{t}}\right]=P
$$

Therefore, the equation required for the iteration of an optimal growth rate is:

$$
\frac{R(1+g)^{n}}{e(1+e)^{n}}\left[\frac{\cdot\left((1+e)^{t}-1\right)}{(1+e)^{t}-(1+g)^{t}}\right]=P-\left(a\left(\frac{\left(1-(1+e)^{-n}\right)}{e}\right)\right)
$$

If the capitalization rate is used to replace its analytical surrogates on the left hand side of equation 16, an alternative formula for the calculation of the implied rental growth rate becomes:

$$
\frac{R(1+g)^{n}}{k(1+e)^{n}}=P-\left(a\left(\frac{\left(1-(1+e)^{-n}\right)}{e}\right)\right)
$$

Although the difference between the short-cut DCF in equations 16 and 17 is the composition of input variables, both equations would churn out identical results for the implied rental growth rate. It can be observed that the calculation of rental growth rate using equation 17 requires the availability of the all risks yield (capitalization rate). If the input of all risks yield is not available, then equation 16 can be used to derive the rental value growth rate.

\subsection{The import of equivalent yield valuation technique in RVGrowth determination}

Wyatt (2013) defines equivalent yield as a single discount rate that is used to capitalize term and reversionary cash inflows of an investment property. This single discount rate implicitly reflects all the characteristics of an investment property including cash flow changes, and value at redemption (Ifediora, 2005). Equivalent yield and all risks yield of an investment property tend to be close but not equal, unless in the case of a fully let freehold. The application of an equivalent yield to conventional technique of property investment valuation is known as "Equivalent yield valuation". Variants of the equivalent yield valuation technique include the term and reversion approach [equation 18]; and the layer or harcore approach [equation 19] (Baum \& Crosby, 2008; Baum et al., 2011; Blackledge, 2009; Brown \& Matysiak, 2000; Scarrett, 2008). The choice of equation [equation 18 or 19] does not matter, since the equivalent yield devoid of any intuitive adjustment is used to discount the cash flows to produce identical valuations.

Where $a=$ rent passing, $R=$ Market rent, $y=$ equivalent yield, and $n=$ number of years to the next rent review, the capital value, $P$ of an interest in freehold property from the perspective of the layer or hardcore approach is modelled as:

$$
P=\frac{a}{y}+\frac{R-a}{y(1+y)^{n}}
$$


On the other hand, the capital value, $P$, of an interest in freehold property from the perspective of the term and reversion approach is modelled as:

$$
P=\left[\left(\frac{a\left((1+y)^{n}-1\right)}{y(1+y)^{n}}\right)+\left(\frac{R}{y(1+y)^{n}}\right)\right]
$$

Notwithstanding the criticisms against the equivalent yield valuation technique, Brown and Matysiak (2000) acknowledged it as the only conventional technique that bridges the gap between implicit- and explicit DCF valuation of reversionary property investments owing to its zero tolerance for yield adjustment at both the term and reversionary cash flow tranches.

It could be recalled that rental growth (RVGrowth) rate iteration can be instantiated using equation 16 or 17 , so that equation 18 is substituted for $P$ in equation 16 to obtain equation 20 :

$$
\frac{R(1+g)^{n}}{e(1+e)^{n}}\left[\frac{\cdot\left((1+e)^{t}-1\right)}{(1+e)^{t}-(1+g)^{t}}\right]=\left[\frac{a}{y}+\frac{R-a}{y(1+y)^{n}}\right]-\left(a\left(\frac{\left(1-(1+e)^{-n}\right)}{e}\right)\right)
$$

Equation 20 is finally restructured as equation 21 in order to facilitate the iteration and calculation of the implied rental growth (RVGrowth) rate per annum:

$$
\frac{R(1+g)^{n} \cdot\left((1+e)^{t}-1\right)}{(1+e)^{t}-(1+g)^{t}}=e(1+e)^{n} \cdot\left(\left(\frac{a}{y}+\frac{R-a}{y(1+y)^{n}}\right)-\left(a\left(\frac{\left(1-(1+e)^{-n}\right)}{e}\right)\right)\right)
$$

Hence, the left hand side of equation 21, which contains the target variable, $g$ shall constitute the focus of this experimental study. Whereas the growth function in equation 21, featured in two places, an explicit variant is obtained as equation 22 by replacing the analytical surrogates of capitalization rate with $k$, provided the all risks yield is known:

$$
(1+g)^{n}=\left(\frac{k(1+e)^{n}}{R}\right) \times\left(\left[\frac{a}{y}+\frac{R-a}{y(1+y)^{n}}\right]-\left(a\left(\frac{\left(1-(1+e)^{-n}\right)}{e}\right)\right)\right)
$$

In other words, equations 21 and 22 shall produce the same results, However, equation 21 is desirable if the value of the capitalization rate $k$ is unknown; otherwise the explicit variant [equation 22] could be used to determine the value of $g$ if capitalization rate $k$ is made available.

\subsection{Groundworks on rental growth rate iteration}

Although Hoesli et al. (2006) have shown, by the application of Monte Carlo techniques, that rental growth rates impact upon exit values in DCF valuations, such analysis, however, is beyond the scope of this study given the need to exhaust contributions to the existing scholarly debates on the deterministic calculation of rental growth rates.

Inquiry into the seminal works of McIntosh and Sykes (1983); McIntosh and Sykes (1985); and Sykes (1984) indicates that the calculation of implied rental growth rate $g$ originated from the import of growth explicit DCF techniques into property investment valuation. From a deterministic perspective, Fraser (1993) demonstrated the use of equation 4 to determine implied rental growth rate. Isaac (2002) further demonstrated the use of equation 4 to calculate the value of $g$ but suggested equation 6 as an alternative deterministic model for that purpose. Similarly, Baum et al. (2011) and French (2006a) demonstrated the use of a variant of equation 5 to calculate the value of $g$. The order of increasing complexity comprises equations $4,5,6$ - followed closely by equation 22 . In the absence of capitalization rate data from comparable transactions, equation 21 comes to the fore, so that an optimal figure representing the value of $g$ at any rent review or valuation epoch would have to be calculated.

While relevant software and spreadsheet tools were recommended to handle such complex analysis (Brown \& Matysiak, 2000; Mackmin, 1988; Wyatt, 2013), valuers were generally advised on the need to assemble the right data to facilitate a correlation between model results and market reality, with the failure to do so of amounting to mere machine manipulation (Mackmin, 1988). Only the seminal works of Brown and Matysiak (2000) and Wyatt (2013) provided scholarly documentations of software iteration leading to the determination of implied rental growth rate using equation 21 as the basis of determination. Although Wyatt (2013) was not specific on the spreadsheet function deployed to calculate $g$, Brown and Matysiak (2000) outlined the three techniques to include 
graphical solution, Excel ${ }^{\circledR}$ Solver, and the use of a customized Excel ${ }^{\circledR}$ Add-in called "RVGrowth". Although Brown and Matysiak (2000) developed an "RVGrowth" algorithm for the calculation of rental growth rate across rent review epochs, the replication requires a working knowledge of Visual BASIC Programming.

Compared to Excel ${ }^{\circledR}$ Solver and Graphical solutions, Excel ${ }^{\circledR}$ Goal Seek appears to be a simpler alternative analytical tool for spreadsheet iteration. However, Brown and Matysiak (2000) did not demonstrate the use of Goal Seek in the calculation of the expected rental growth rate, $g$ at the time of their research. In this study, the application of Goal Seek for the iteration and calculation of expected rental growth was driven by insights from the seminal work of Baum et al. (2011), where it was used to determine internal rates of return in DCF appraisals. For this study, equation 23 was restructured from equation 21 to facilitate the computation of $g$ using Excel $^{\circledR}$, Goal Seek and Solver Add-in respectively, where all input variables retain their original meaning as detailed in the preceding section:

$$
\begin{aligned}
& \left(R^{*}\left(\left((1+e)^{\wedge} n\right)-1\right)\right)^{*}\left((1+g)^{\wedge} n\right) /\left(\left((1+e)^{\wedge} t\right)-\left((1+g)^{\wedge} t\right)\right)=\left(e^{*}\left((1+e)^{\wedge} n\right)\right)^{*}\left(\left((a / y)+\left((R-a) /\left(\left(y^{*}(1+y)^{\wedge}-n\right)\right)\right)\right)-\left(a^{*}((1-\right.\right. \\
& \left.\left.\left.\left.\left((1+e)^{\wedge}-n\right)\right) / e\right)\right)\right)
\end{aligned}
$$

Similarly, the complexity in the calculation of $g$ was minimized following the determination of all risks yield using Excel $^{\circledR}$ compatible format of equation 13:

$$
\text { All risks yield, } k_{0}=\left(\left(\left(e^{*}\left((1+e)^{\wedge} t\right)-e^{*}\left((1+g)^{\wedge} t\right)\right)\right) /\left(\left(\left((1+e)^{\wedge} n\right)-1\right) *\left((1+g)^{\wedge} n\right)\right)\right)
$$

Brown and Matysiak (2000) further determined freehold implied rental growth rate by graphically solving two simultaneous algebraic equations leading to the intersection of periodic growth function with the equivalent yield function. An alternative explored in this paper was to solve the root of a polynomial equation arising from the synthesis of the equivalent yield model and the growth explicit DCF model drawn from equation 21.

Excerpts from the seminal work of Brown and Matysiak (2000) indicate that the process of RVGrowth rate iteration remains the same for all freehold investment properties irrespective of their uses. For instance, if real estate is put to use as an office, a shop, a warehouse, recreational facility, or residential apartment, the procedure for RVGrowth rate iteration shall remain the same provided they are reversionary freeholds exhibiting income profiles as depicted in Figure 1. However, where these properties are held under the tenure of derivative interests or leaseholds, the process of RVGrowth rate determination shall require a different dimension of DCF modelling and spreadsheet iteration, which is beyond the scope of this study, but the subject of further research.

\section{Data and Methods}

\subsection{Data requirements}

An experimental design was set up in the form of scenario analysis to address the study. These include equations and data required in the equivalent yield valuation model and the short-cut explicit DCF valuation model respectively. Data include the equivalent yield, contract rent, market rent, equated yield, period to next rent review, and the standard rent review period; for the purpose of calculating the rental value growth (RVGrowth) rate and all risks yield respectively. The data were drawn from a hypothetical case of a simple reversionary freehold investment property let on a full repairing and insuring lease, with contract rent payable per annum in arrears and subject to 3 yearly upward reviews. The valuation case study in section 4.1 comprises six of these data except for the calculation of the all risks yield, $k$ and the spreadsheet iteration of the rental growth rate, $g$ using spreadsheet iteration and root-solving tools for polynomial equations arising from the short-cut DCF appraisal. The author had chosen to express the currency for this experimental study in Naira (The official currency of Nigeria, being the experimental study area). Investment functions, such as present value $[\mathrm{PV}]$, and present value of annuities or Years purchase, among others, are expressed in the index value of 1 , so that the choice of currency is immaterial (Blackledge, 2009), unless a currency conversion is desirable. In order to accord global application to the analytical content of this article, a currency conversion rate of $\$ 1$ to $€ 0.0022$ as of 7th August 2020 (Google Finance, 2020) may be applied. Therefore, an interested reader of this article should simply multiply the quoted figure in Naira by $€ 0.0022$ in order to get the Euro equivalent. 


\subsection{Software specifications and scenario analysis tools}

The experimentation process could be performed using any hardware computer with a spreadsheet and mathematical software package. While any type of spreadsheet package capable of performing "What-If" analysis can be utilized in a study like this, the author's preference was drawn to Microsoft ${ }^{\circledR} \mathrm{Excel}^{\circledR}$ owing to its popularity in the author's geographical location. Secondly, KyPlot ${ }^{\circledR}$ was chosen as an example of a mathematical software package with graphing and root-solving functions for the purpose of the study.

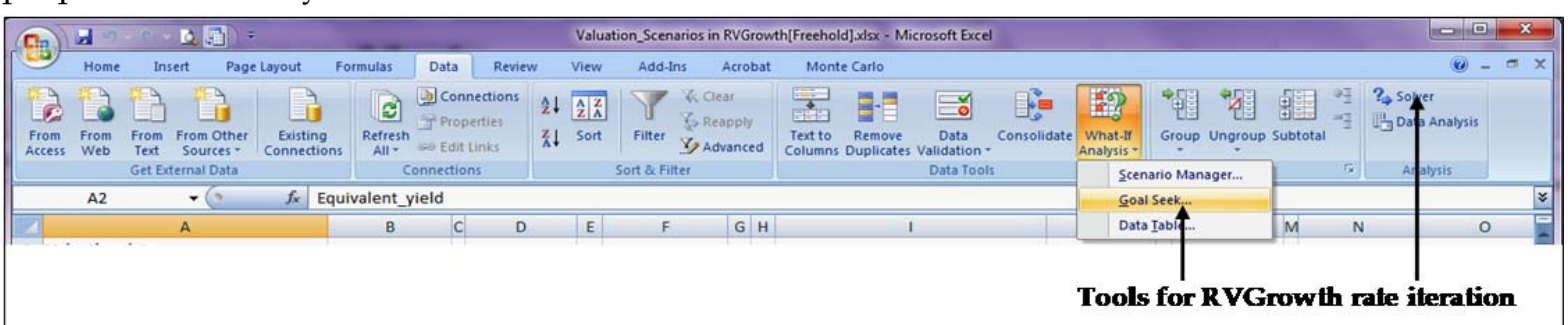

Fig. 2: Tools of experimentation and rental value growth (RVGrowth) calculation in Excel ${ }^{\circledR}$. Source: own study.

Within the Excel ${ }^{\circledR}$ environment [Figure 2] are two related scenario analysis tools, namely Goal Seek, which is embedded in the "What-If" Data tool, and the Solver Add-in, which is an extension of the "What-If" analysis. Goal Seek was specifically used to iterate and determine the equivalent yields and implied rental growth rate across the valuation epochs.

For the calculation of equivalent yield [See Tables 5 to 8], the goal seek function was instantiated using the Data Toolbar > Data tools > What-If Analysis > Goal seek command; so that the target cell for Net Present value was set at 0.00 by varying the input cell for the equivalent yield. Clicking the OK button returns the equivalent yield at the specific valuation/rent review epoch.

For the calculation of the implied rental growth rate, the Goal Seek function was instantiated using the Data Toolbar > Data tools > What-If Analysis > Goal seek; so that the target cell for capital value in the short-cut DCF technique was equated with that derived from the equivalent yield technique by changing cell "B8" representing the input cell for the implied rental growth rate.

As an alternative to the Goal seek function, the Excel ${ }^{\circledR}$ Solver Add-in was instantiated to solve rental growth rate across the rent review epochs using the procedure: Data Toolbar > Analysis > Solver command; so that the target cell for capital value in the short-cut DCF technique was equated with that derived from the equivalent yield technique by changing cell "B8" for the implied rental growth rate.

For both the Goal Seek and Solver dialog boxes, clicking the OK button returned the optimal rental growth rate and commanded the spreadsheet to recalculate the all risks yield leading to a real-time change in the initial structure of short-cut DCF valuations such that the ensuing capital values equate with those obtained from the equivalent yield model.

The root-finding algorithm and graphing tool of Version 2.0 of $\mathrm{KyPlot}^{\circledR}$ was used to determine the zeros of polynomial equations representing the implied rental growth (RVGrowth) rates across each rent review epoch. The polynomial function was derived on the condition that the rational root satisfies the equation $1+g>0$ and $(1+e)<(1+g)$, so that the RVGrowth rate can be expressed as a percentage by subtracting 1 and multiplying by $100 \%$. As a precaution, a (single) positive rational root of the polynomial equation which satisfies the theory of upward revision of rent as put forward in this study was chosen. Secondly, where multiple (positive) rational roots are obtained, the choice of which represents the RVGrowth rate, shall be identical to iteration results from the alternative methods.

\subsection{Presentation techniques for scenario analysis of implied rental growth rate}

Data associated with this study were presented using Figures and Tables. The figures comprise screenshots of the graphic user interface (GUI) of appraisals and scenario analysis, and graphs. Secondly, specific tables were dedicated to the presentation of short-cut DCF valuations, equivalent yield appraisals, and a summary of the results of appraisals and rental growth at specific epoch of rent review or valuation. Drawn from these figures and tables is, among others, an analysis of the interrelationships among the input and output parameters as well as the implications for investment decisions pertaining to reversionary freeholds. For analytical purposes, the accuracy of the IRR in this 
study was presented in nine decimal places so as to ensure that the calculation of the implied rental growth rate across the techniques of graphing/root-solving tool, Excel ${ }^{\circledR}$ Solver and Goal Seek produced identical results. Preliminary alteration of the IRR to say two or three decimal places prior to the appraisal shall Systematically produce undesired results for capital values in Tables 2 to 5 , the NPV in Tables 6 to 9 and the final outcome of RVGrowth rate being iterated. However, the summary of iterated RVGrowth alongside the yield parameters, including the equivalent yield [i.e the implicit IRR] in Table 10, were presented in two decimal places for the readers' convenience. Unless otherwise stated, all tables, diagrams, and screenshots are products of the author's own study.

\section{Empirical results}

\subsection{The valuation case study}

The valuation case pertains to a block of 4 No. Shops held as a reversionary freehold investment property with $7.165117664 \%$ growth implicit internal rate of return [IRR] and market rent of $\mathrm{N}, 010,000$. Let it be assumed that the block of No. 4. Freehold shops were let today at a rent of ₹2,050,000 subject to 3-yearly upward reviews. If the property investor expects a nominal return of about $20.5 \%$, attempts shall be made in this study to calculate the all risks yield, and then determine, through spreadsheet iteration, the implied rental growth (RVGrowth) of the investment property across four valuation epochs, namely 3 years to the next rent review, 2 years to next rent review, 1 year to next rent review, and at full reversion to market rent. For the purpose of currency conversion, it should be recalled that $¥ 1$ exchanged for $€ 0.0022$ as of 7 th August, 2020. Table 1 summarizes the data set utilized for this experimental study.

Table 1

The hypothetical data set for the experimental study

\begin{tabular}{|c|c|c|}
\hline Attribute & Value & Remarks \\
\hline Property description & A block containing 4 shops & \\
\hline Type of interest held & Reversionary freehold & \\
\hline Duration of interest held & Perpetuity & \\
\hline Equivalent yield & $7.165117664 \%$ & \\
\hline Passing rent & $\mathrm{N} 2,050,000$ & \\
\hline Market rent & $¥ 3,010,000$ & \\
\hline Equated yield & $20.5 \%$ & \\
\hline Valuation epoch 1 & 3 years to next rent review & \\
\hline Valuation epoch 2 & 2 years to next rent review & \\
\hline Valuation epoch 3 & 1 year to next rent review & \\
\hline Valuation epoch 4 & Full reversion to market rent & \\
\hline Implied rental growth rate & Initially unknown & To be iterated \\
\hline All risks yield & Initially unknown & To be calculated \\
\hline
\end{tabular}

Source: own study.

The succeeding sections provide a documentation of how the expected growth rate was determined across the rent review epochs.

\subsection{The base case valuation in Microsoft ${ }^{\circledR}$ Excel $^{\circledR}$}

Equations 12 and 18 were used to create a base case valuation scenario in Excel ${ }^{\circledR}$. As shown in Figure 3 , when the passing rent is due for upward revision in 3 years' time, the sum of term and reversionary cash flows discounted at an equivalent yield of $7.165117664 \%$ is put at $\$ 39,497,317.41$.

This valuation constituted the basis for the calculation of the RVGrowth rate using three approaches of scenario analysis; namely the Goal Seek and Solver in MS Excel ${ }^{\circledR}$, and root solving algorithms for polynomial equations arising from equation 23 . 


\section{S sciendo}

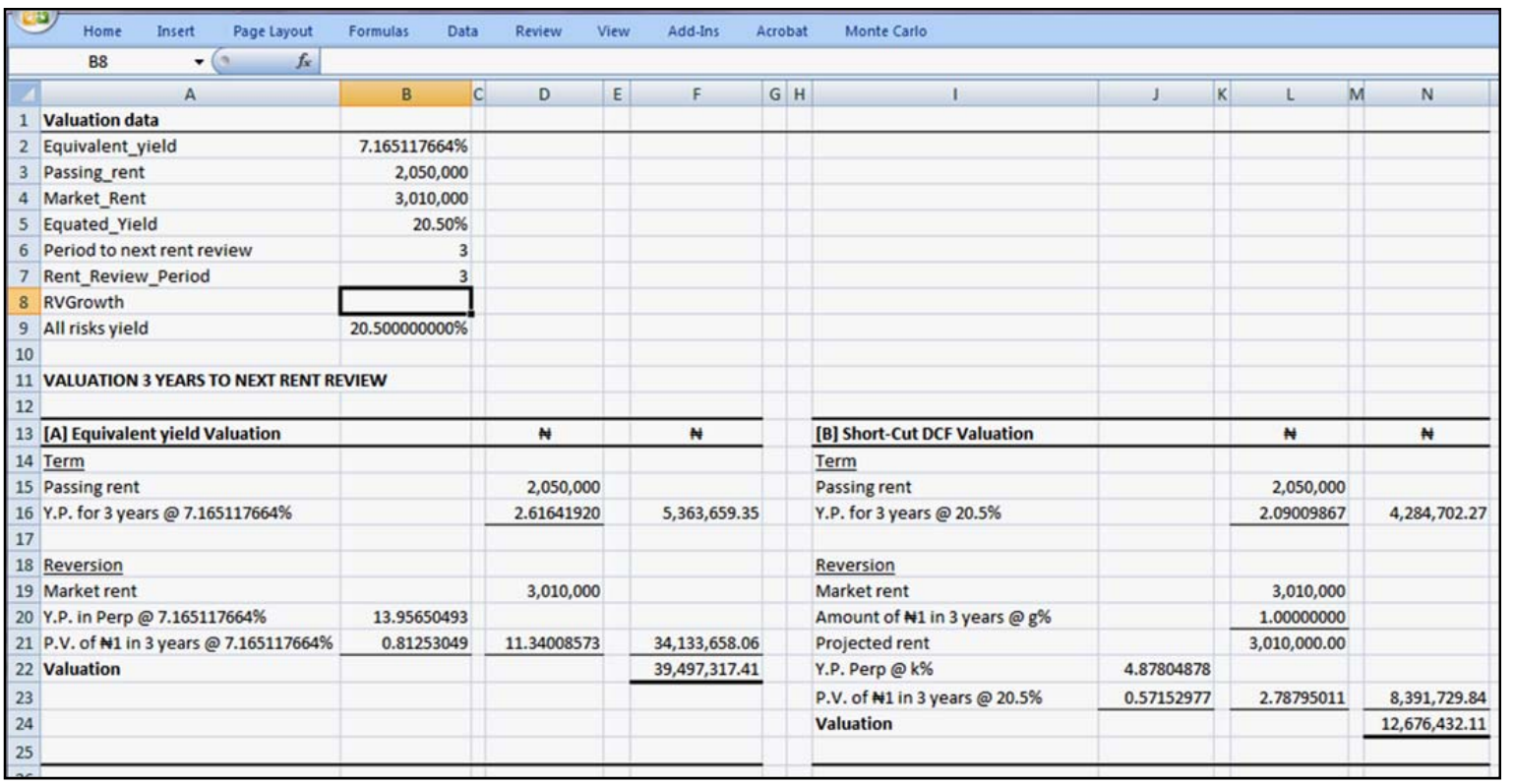

Fig. 3. Screenshot of base case appraisal in Microsoft ${ }^{\circledR}$ Excel $^{\circledR}$. Source: own study.

\subsection{Rental value growth rate calculation using the Goal seek function}

At the commencement of the lease, the freehold investment property has 3 years to the next revision of contract rent. The equivalent yield technique returned a capital value of $\$ 39,497,317.41$ at this epoch. For this scenario, a short-cut DCF appraisal was set up in Figure 4 and subjected to the Goal Seek analysis which determined the RVGrowth rate in Figure 5 as $14.075 \%$ per annum.

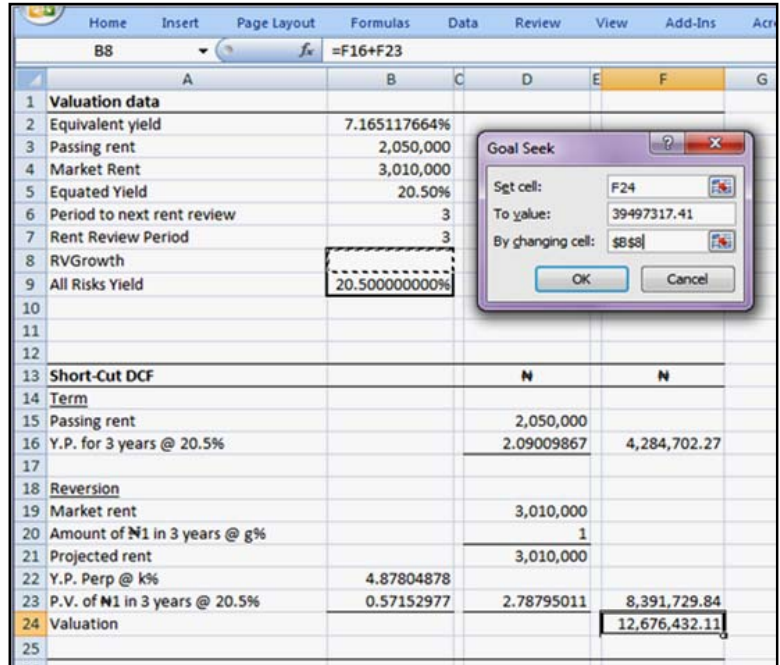

Fig. 4: Input GUI for goal seek operations. Source: own study.

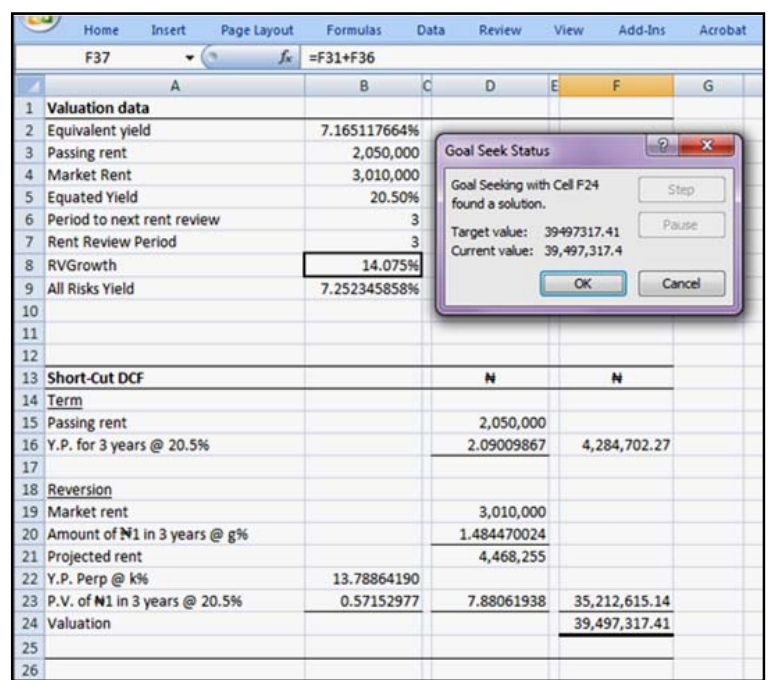

Fig. 5: Output GUI for goal seek operations. Source: own study.

Upon iteration and calculation of the RVGrowth rate as $14.075 \%$ per annum, contents of cells for the short-cut DCF valuation linked to the RVGrowth in Figure 5, including the all risks yield in Cell "B9" and the capital value of the freehold interest in cell "F24", were altered to the tune of $7.252345858 \%$ and $\$ 39,497,317.41$ respectively.

\subsection{Rental value growth rate calculation using the Solver Add-in}

When the contract rent at the commencement of the lease was due for upward revision in 3 years' time the equivalent yield technique returned a capital value of $\$ 39,497,317.41$. 


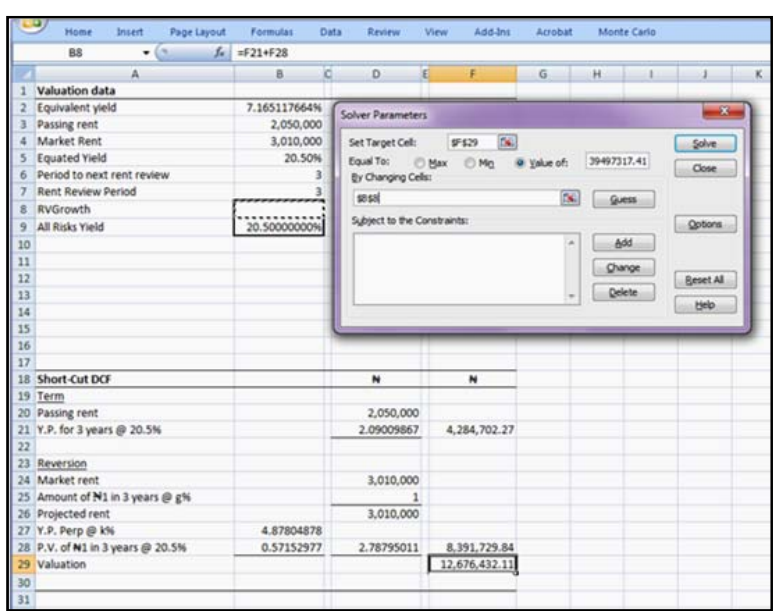

Fig. 6: Input GUI for Excel ${ }^{\circledR}$ solver operations. Source: own study.

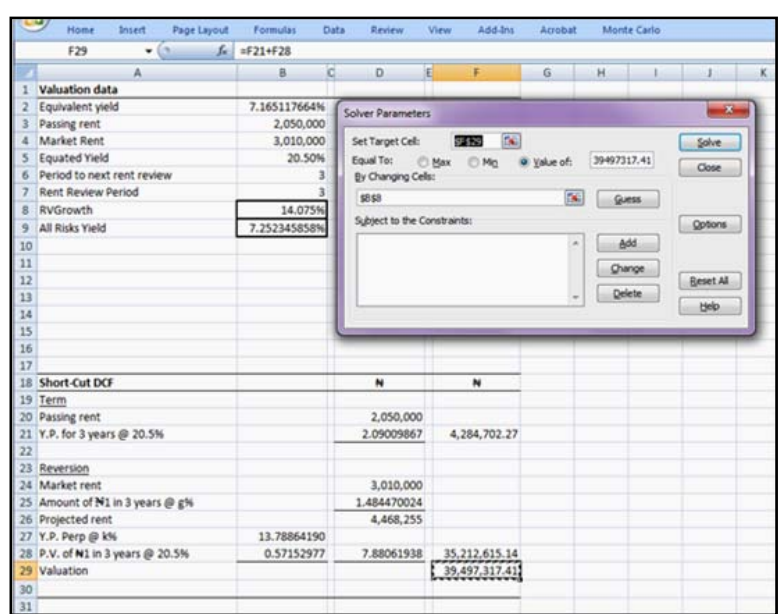

Fig. 7: Output GUI for Excel ${ }^{\circledR}$ solver operations. Source: own study.

This capital value was further used to induct the RVGrowth to the tune of $14.075 \%$ per annum using a synthesis of short-cut DCF appraisal and Excel ${ }^{\circledR}$ Solver Add-in. Just as in sub-section 4.3, the analyses in Figures 6 and 7 returned an all risks yield and DCF capital value of 7.252345858\% and $\$ 39,497,317.41$ in cells "B9" and 'F24" respectively. In other words, the application of Excel ${ }^{\circledR}$ Goal Seek and Solver Add-in produced identical valuations.

\subsection{Rental value growth rate calculation using roots of polynomial equations}

With the valuation data provided in Figure 3, equation 21 was populated to arrive at the following:

$$
\begin{aligned}
& \frac{3,010,000(1+g)^{3} \cdot\left((1.205)^{3}-1\right)}{(1.205)^{3}-(1+g)^{3}}=0.205(1.205)^{3} \cdot\left(\left(\frac{2,050,000}{0.07165117664}+\frac{3,010,000-2,050,000}{0.07165117664(1.07165117664)^{3}}\right)-\left(2,050,000\left(\frac{\left(1-(1.205)^{-3}\right)}{0.205}\right)\right)\right) \\
& \frac{2,256,567.28(1+g)^{3}}{1.749690125-(1+g)^{3}}=0.358686475 \times((28,610,835.11+10,886,482.30)-4,284,702.27)
\end{aligned}
$$

The mathematical expression above was reduced to a cubic equation as: $14,886,856.08(1+g)^{3}-22,099,091.59=0$. So that if $(1+g)=X$, then the equation 25 below is obtained:

$$
f(X)=14,886,856.08 X^{3}-22,099,091.59
$$

Using the Math tool bar in $\mathrm{KyPlot}^{\circledR}$, the roots of equation 25 were returned to include a positive non-integer of 1.14075, and a repeated negative non-integer of -0.570374999 respectively. These negative non-integers were discarded in favour of the positive non-integer, 1.14075. In a related development, the graphing tool of $\mathrm{KyPlot}^{\circledR}$ was used to plot Equation 25 within the range: $-4 \leq X \leq+5$, [Figure 8]. In which case $f(X)$ represents the Future Value [FV] of cash flows (annuity) plotted on the vertical axis, while the sum of unity and the implied rental growth rate " $(1+\mathrm{g})$ " was plotted on the horizontal axis. As shown in Figure 8, the positive non-integer root of the function was zoomed to cross the horizontal axis at approximately 1.14075 .

Subtracting 1 from 1.14075 and multiplying the ensuing figure by $100 \%$ resulted in $14.075 \%$ per annum as the implied rental growth (RVGrowth) rate for the freehold investment property. Hence, the root solving algorithm in KyPlot ${ }^{\circledR}$ was further found to achieve identical results with the Excel ${ }^{\circledR}$ Goal Seek and Solver tools for the calculation of growth rate of freehold cash flows valued part-way through rent review periods. 


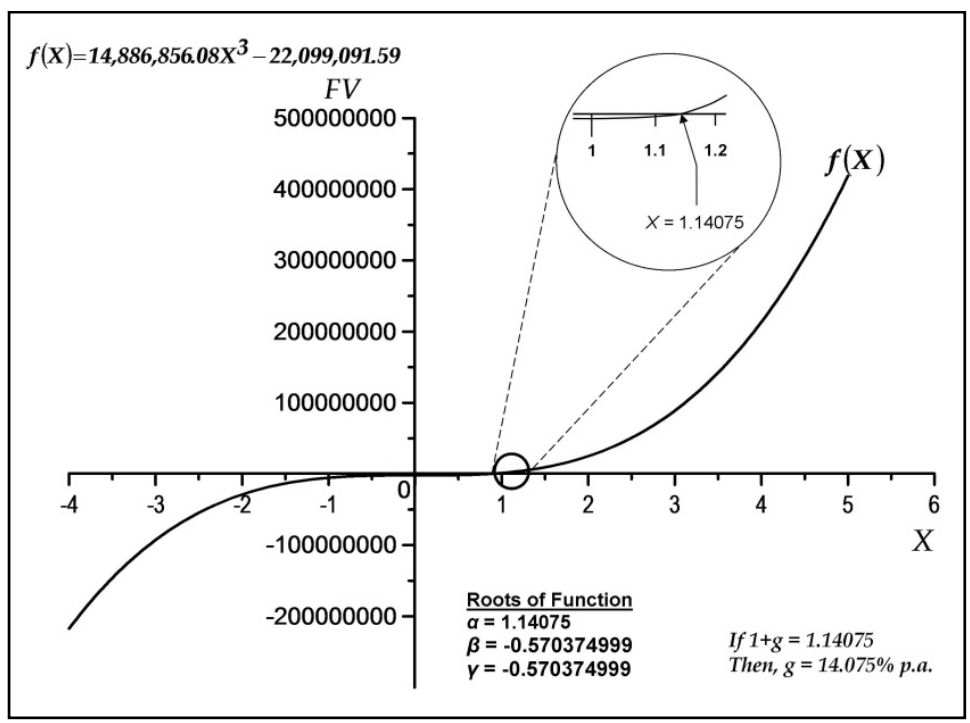

Fig. 8. Graphical solution to RVGrowth rate calculation. Source: own study.

\subsection{Short-cut DCF Valuations across specific epochs to the upward review of contract rent}

It is assumed from the results of the valuation scenario in Figures 5 and 7 that the six inputs exhibiting consistent values required for accurate valuation across specific valuation epochs include passing rent, market rent, equated yield, rent review period, rental value growth rate (RV Growth), and the all risks yield.

Results in Tables 2 to 5 indicate that the short-cut DCF valuation of the freehold investment property shall be $\$ 39,497,317.41$ when rent is due for review in 3 years' time; $\$ 40,308,947.23$ when rent is due for upward review in 2 years' time; $\$ 40,992,094.34$ when rent is due for upward review in 1 year's time and $\$ 41,503,812.13$ upon full reversion of the freehold interest. All these valuations were predicated on an implied annual growth rate of $14.075 \%$ per annum determined in sections $4.3,4.4$, and 4.5. The short-cut DCF valuations in Tables 2 to 5 were further used to calculate the equivalent yields of the freehold investment property across the specific valuation/rent review epochs.

\subsection{Equivalent yield calculations across the valuation epochs}

Within the Excel ${ }^{\circledR}$ environment, the growth implicit DCF appraisal in Tables 6 to 9 were set up to facilitate the calculation of the equivalent yield of the freehold investment property across the rent review epochs.

Results of the Goal Seek analysis in Tables 6 to 9 indicate that the freehold equivalent yield shall be $7.165117664 \%$ when rent is due for review in 3 years' time; $7.159709820 \%$ when rent is due for upward review in 2 years' time; $7.185874381 \%$ when rent is due for upward review in 1 year's time and $7.252345858 \%$ upon full reversion of the freehold interest. The equivalent yield appraisal in the last epoch affirmed the assertion that equivalent yield and all risks yield shall be identical for fully let freeholds.

\subsection{Rental growth calculation across the remaining rent review epochs}

The Goal Seek tool was selected and applied to the remaining rent review/valuation epoch owing to its relative simplicity and ease of use. The short-cut DCF valuations in Tables 1 to 4 and the equivalent yields determined in Tables 6 to 9 were used to perform What-If analysis leading to the iteration and verification of the rental growth rates across the specific valuation epochs.

When the contract rent is due for upward revision in 2 years' time, it can be recalled that Table 7 returned 7.159709820\% equivalent yield for $\$ 40,308,947.23$ market price. The Goal Seek function was instantiated in Figure 9 to return a calculated rental growth of $14.075 \%$ per annum, which altered the content of the cells for the short-cut DCF valuation in Figure 9, including the all risks yield in Cell "B9" and the capital value of the freehold interest in cell "F24" to $7.252345858 \%$ and $\$ 40,308,947.23$ respectively, as shown in Figure 10. In other words, the short-cut DCF valuation in Figure 10 is 


\section{S sciendo}

identical to that in Table 3 following the stabilization of RVGrowth rate and all risks yield at $14.075 \%$ and $7.252345858 \%$ respectively.

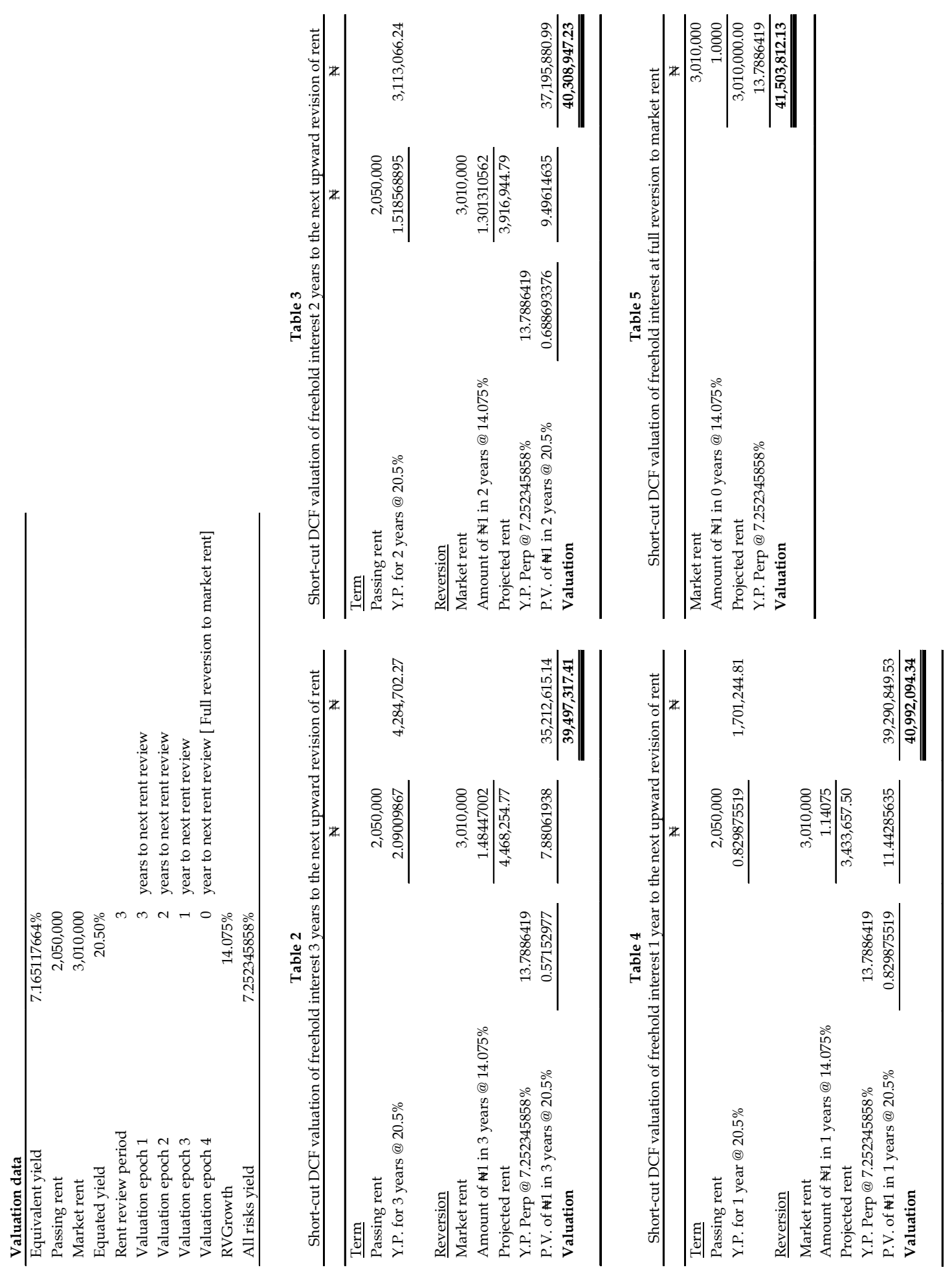


Table 6

Equivalent yield of freehold interest 3 years to next review of contract rent

\begin{tabular}{|c|c|c|c|c|}
\hline \multicolumn{2}{|c|}{ Capital value of property: } & \multicolumn{2}{|l|}{ N39,497,317.41 } & \\
\hline \multicolumn{2}{|c|}{ Equivalent Yield, Rx: } & \multicolumn{2}{|l|}{$7.165117664 \%$} & \\
\hline Year & Cash inflow & Y.P. in Perp. @ Rx & P.V.@ Rx\% & Present Value \\
\hline 1 & $2,050,000$ & & 0.93313946 & $1,912,935.89$ \\
\hline 2 & $2,050,000$ & & 0.870749251 & $1,785,035.97$ \\
\hline 3 & $2,050,000$ & & 0.812530486 & 1665687.496 \\
\hline \multirow[t]{2}{*}{4 - Perp. } & $3,010,000$ & 13.956504930 & 0.812530486 & $34,133,658.06$ \\
\hline & \multicolumn{3}{|c|}{ 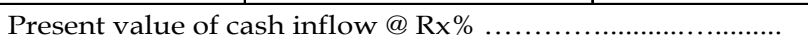 } & $39,497,317.41$ \\
\hline \multirow[t]{2}{*}{$\underline{\text { Less }}$} & \multicolumn{3}{|c|}{ 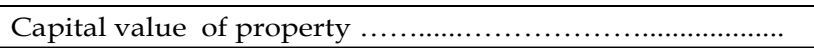 } & $39,497,317.41$ \\
\hline & \multicolumn{3}{|c|}{ Net Present Value } & 0.00 \\
\hline
\end{tabular}

Table 7

Equivalent yield of freehold interest 2 years to next review of contract rent

\begin{tabular}{|c|c|c|c|c|}
\hline \multicolumn{2}{|c|}{ Capital value of property: } & \multicolumn{2}{|l|}{ N40,308,947.23 } & \\
\hline \multicolumn{2}{|c|}{ Equivalent Yield, Rx: } & \multicolumn{2}{|l|}{$7.159709820 \%$} & \\
\hline Year & Cash inflow & Y.P. in Perp. @ Rx & P.V. @ Rx\% & Present Value \\
\hline 1 & $2,050,000$ & & 0.933186551 & $1,913,032.43$ \\
\hline 2 & $2,050,000$ & & 0.870837139 & $1,785,216.13$ \\
\hline 3 & $3,010,000$ & & 0.812653506 & $2,446,087.05$ \\
\hline 4 - Perp. & $3,010,000$ & 13.967046502 & 0.812653506 & $34,164,611.61$ \\
\hline \multicolumn{4}{|c|}{ Present value of cash inflow @ Rx\% .............................. } & $40,308,947.23$ \\
\hline$\underline{\underline{\text { Less }}}$ & \multicolumn{3}{|c|}{ 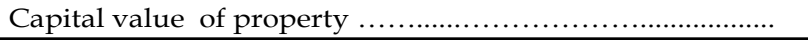 } & $40,308,947.23$ \\
\hline \multicolumn{4}{|c|}{ 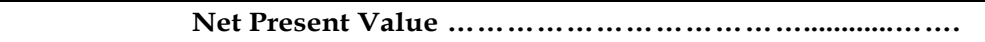 } & 0.00 \\
\hline
\end{tabular}

Table 8

Equivalent yield of freehold interest 1 year to next review of contract rent

\begin{tabular}{|c|c|c|c|c|}
\hline \multicolumn{2}{|c|}{ Capital value of property: } & \multicolumn{2}{|l|}{$\$ 40,992,094.34$} & \\
\hline \multicolumn{2}{|c|}{ Equivalent Yield, Rx: } & \multicolumn{2}{|l|}{$7.185874381 \%$} & \\
\hline Year & Cash inflow & Y.P. in Perp. @ Rx & P.V.@ Rx\% & Present Value \\
\hline 1 & $2,050,000$ & & 0.932958756 & $1,912,565.45$ \\
\hline 2 - Perp. & $3,010,000$ & 13.916190945 & 0.932958756 & $39,079,528.89$ \\
\hline \multicolumn{4}{|c|}{ 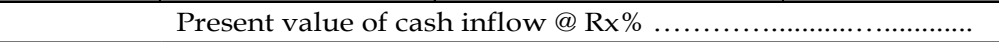 } & $40,992,094.34$ \\
\hline \multirow[t]{2}{*}{$\underline{\underline{\text { Less }}}$} & \multicolumn{3}{|c|}{ 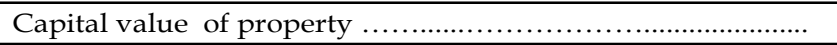 } & $40,992,094.34$ \\
\hline & \multicolumn{3}{|c|}{ 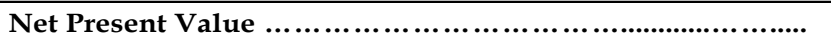 } & 0.00 \\
\hline
\end{tabular}

Table 9

Equivalent yield of freehold interest at full reversion

\begin{tabular}{|c|c|c|c|c|}
\hline \multicolumn{2}{|c|}{ Capital value of property: } & \multicolumn{2}{|l|}{ N41,503,812.13 } & \\
\hline \multicolumn{2}{|c|}{ Equivalent Yield, Rx: } & \multicolumn{2}{|l|}{$7.252345858 \%$} & \\
\hline Year & Cash inflow & Y.P. in Perp. @ Rx & P.V.@ Rx\% & Present Value \\
\hline 1 & $3,010,000$ & & 0.932380539 & $2,806,465.42$ \\
\hline 2 - Perp. & $3,010,000$ & 13.788641904 & 0.932380539 & $38,697,346.71$ \\
\hline \multicolumn{4}{|c|}{ Present value of cash inflow @ Rx\% ................................ } & $41,503,812.13$ \\
\hline \multirow[t]{2}{*}{$\underline{\underline{\text { Less }}}$} & \multicolumn{3}{|c|}{ 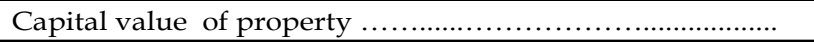 } & $41,503,812.13$ \\
\hline & \multicolumn{3}{|c|}{ Net Present Value } & 0.00 \\
\hline
\end{tabular}

When the contract rent is due for upward revision in 1 year's time, Table 8 returned $7.185874381 \%$ equivalent yield for market price in the sum of $\$ 40,992,094.34$. The instantiated Goal Seek in Figure 11 returned a calculated rental growth of $14.075 \%$ per annum which altered the content of the cells for the short-cut DCF valuation in Figure 11 including the all risks yield in Cell "B9" and the capital value in cell "F24" to $7.252345858 \%$ and $40,992,094.34$ respectively as shown in Figure 12. Likewise, the short-cut DCF valuation in Figure 12 appeared identical to that in Table 4, as RVGrowth rate and all risks yield stabilized at $14.075 \%$ and $7.252345858 \%$ respectively. 


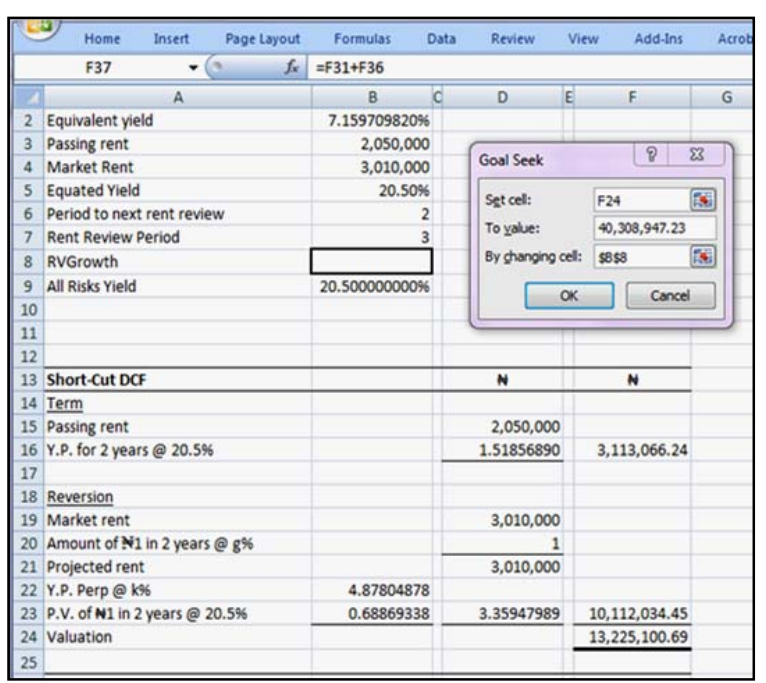

Fig. 9. Invoking Goal Seek to find growth rate at 2 years to contract rent revision. Source: own study.

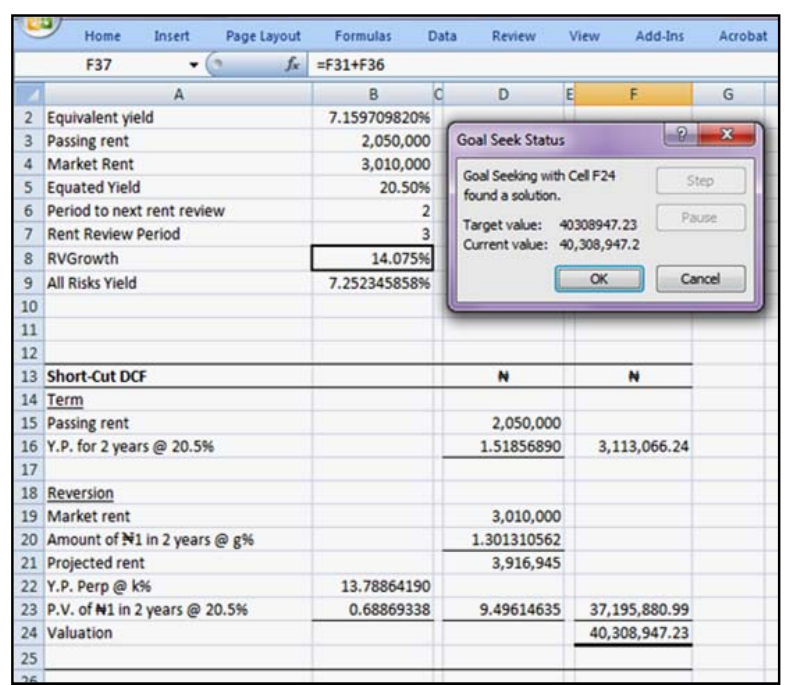

Fig. 10. Calculated RVGrowth at 2 years to contract rent revision. Source: own study.

Upon the full reversion of the freehold interest, spreadsheet iteration in Table 9 returned $7.252345858 \%$ equivalent yield, which is equal to the all risks yield, culminating into a market price of $\$ 41,503,812.13$ for the freehold investment property when fully let at the market rent of $\$ 3,010,000$. The RVGrowth rate was calculated as $14.075 \%$ per annum following the deployment of the Goal Seek in Figure 13 so that the short-cut DCF valuation in Figure 14 became identical to that in Table 5, as RVGrowth rate and all risks yield remained constant at $14.075 \%$ and $7.252345858 \%$ respectively.

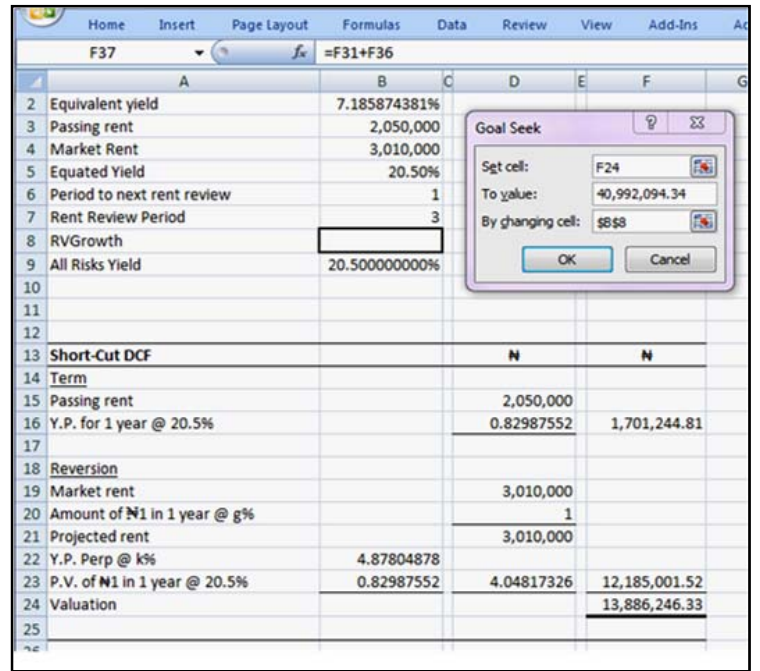

Fig. 11. Invoking Goal Seek to find growth rate at 1 year to contract rent revision. Source: own study.

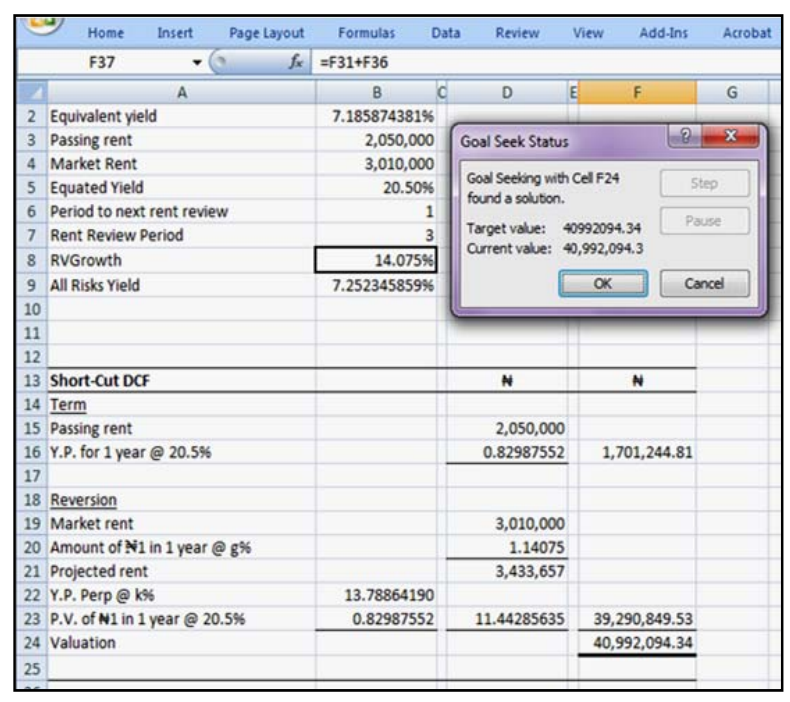

Fig. 12. Calculated RVGrowth at 1 year to contract rent revision. Source: own study.

\subsection{Summary of results across the valuation epochs}

Presented in Table 10 is the summary of rental value growth (RVGrowth) appraisal carried out across the valuation epochs. At this juncture, the results have been uniformly presented in 2 decimal places for readers' convenience. Notwithstanding the decline in the number of years to the next revision of contract rent, the $14.08 \%$ per annum RVGrowth rate (to 2 decimal places) upon which the short-cut DCF valuation depends shall remain constant throughout the term and reversion of the freehold interest if sales prices of either $\$ 39,497,317.41$, $\$ 40,308,947.23$, or $\$ 40,992,094.34$ are realized before full reversion in the 1st, 2 nd, or 3rd valuation epoch respectively; or if a price of $\$ 41,503,812.13$ is realized from the sale of freehold investment property when fully let. The Euro equivalents of these valuations have been documented in Table 10. 


\section{S sciendo}

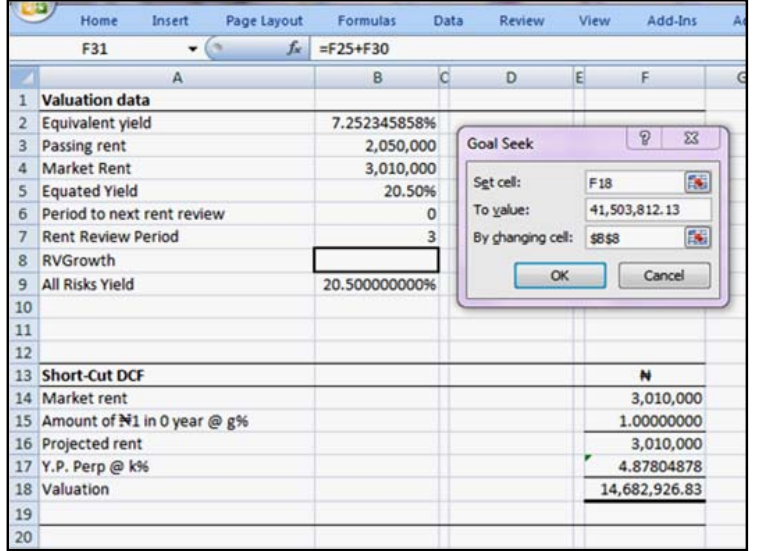

Fig. 13. Goal Seek invoked to find RVGrowth at full reversion. Source: own study.

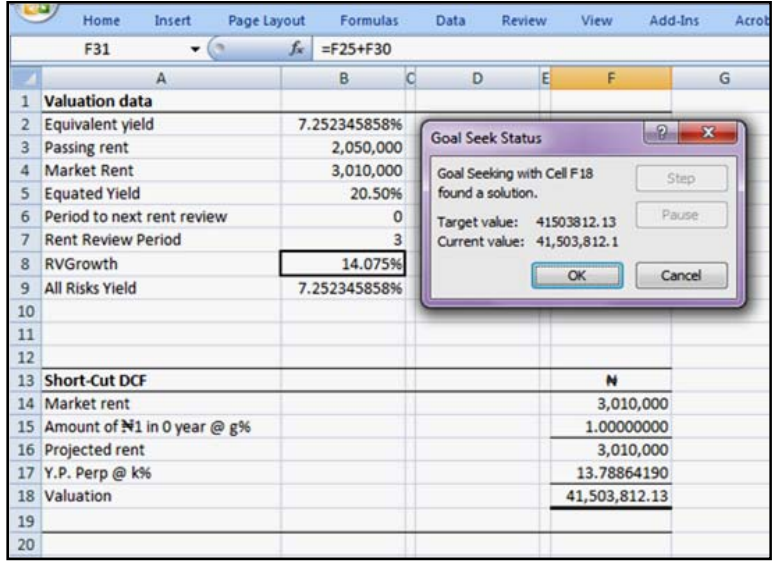

Fig. 14. Calculated RVGrowth at full reversion Source: own study.

The hypothetical case of reversionary freehold interest posed in this study has revealed that the full price of freeholds let at cash inflows below the market rent may not be realized until a full reversion of the lease to the freeholder. It can be observed in Table 10 that the ratio of valuation at a given epoch to the valuation at full reversion increases steadily as the contract rent approaches the revision date.

Table 10

Rental value growth calculation and its impact on other freehold investment parameters

\begin{tabular}{|c|c|c|c|c|}
\hline \multirow[b]{2}{*}{ Investment parameters } & \multicolumn{4}{|c|}{ Valuation epochs/Years to next rent revision } \\
\hline & 3 years & 2 years & 1 year & $\begin{array}{c}0 \text { years } \\
\text { (Full reversion) }\end{array}$ \\
\hline Equivalent yield (\%) & 7.17 & 7.16 & 7.19 & 7.25 \\
\hline All risks yield $(\%)$ & 7.25 & 7.25 & 7.25 & 7.25 \\
\hline Equated yield (\%) & 20.50 & 20.50 & 20.50 & 20.50 \\
\hline RVGrowth rate per annum (\%) & 14.08 & 14.08 & 14.08 & 14.08 \\
\hline Capital value in Naira ( & $39,497,317.41$ & $40,308,947.23$ & $40,992,094.34$ & $41,503,812.13$ \\
\hline $\begin{array}{l}\text { Capital value in Euros }(€) \\
{[\mathrm{N1}=€ 0.0022 \text { as at } 7 \text { Aug. } 2020]}\end{array}$ & $86,894.10$ & $88,679.68$ & $90,182.61$ & $91,308.39$ \\
\hline $\begin{array}{l}\text { Percentage of capital value to } \\
\text { value at full reversion }(\%)\end{array}$ & 95.17 & 97.12 & 98.77 & 100.00 \\
\hline
\end{tabular}

Source: own study.

\section{Discussions and conclusion}

This article is an extended contribution to the analytical tools that can be used to calculate implied rental growth rate of a freehold investment property valued part-way through rent review epoch. Although deterministic in outlook, the three procedures of Excel ${ }^{\circledR}$ Goal Seek, Excel ${ }^{\circledR}$ Solver, and Rootsolver for polynomial equation are capable of producing identical results for the growth rate implied in the all risks yield and the capital value of freehold interest. These three techniques for implied rental growth iteration are generally improvements over simple model illustrations in Baum et al. (2011), Fraser (1993), French (2006a) and Isaac (1998, 2002), which cannot handle the complicated tasks of rental growth rate iteration for freeholds valued between rent review epochs.

All the three automated processes for the iteration and calculation of implied rental growth rate of a freehold investment property across specific valuation epochs produced identical results for rental growth and the all risks yield respectively. For the appraisal of a specific freehold interest, rental growth rate and all risks yield shall remain constant, while the equivalent yield across the epochs may eventually increases as the contract rent approaches the renewal date until it equates with the all risks yield at full reversion. By implication, the capital value of an under-rented freehold interest increases gradually at each rent review epoch until it is realized at $100 \%$ value at full reversion, where it is assumed that the property can be let at the market rent. Therefore, the purchase of freehold 
investment properties at epochs prior to full reversion would tend to be a favourable decision contrary to the purchase at full reversion. On the other hand, the sale of the same investment property at full reversion may tend to favour the freeholder compared to periods prior to full reversion.

Just as in a cognate study of Monte Carlo simulation for real estate valuation credited to Hoesli $e t$ al. (2006), this experimental research is not without limitations. An equivalent yield-derived property value is required to calculate the expected growth rate from the short-cut DCF model. However, this growth implicit yield cannot be determined in practice without knowledge of a comparable sales price. Secondly, the assumption that equated yield remains constant may be challenged by the phenomenon of time-varying equated yields arising from changes in risk premium over time (Baum, 2009; Jones et al., 2015; Wyatt, 2013) especially across the rent review epochs. Thirdly, the implied rental growth rate is only a geometric mean of the Year-on-Year change in rental values and is implied in the all risks yield. It is however possible that this geometric mean growth rate might be altered when recalculated using progressively distinct values for the Year-on-Year change in rental values, which, in turn, might lead to a significant change in the all risks yield across the rent review epoch.

Similarly to the case of software iterations and scenario analyses, the veracity of outputs is anchored on the reliability and robustness of inputs (Hoesli et al., 2006; Li, 2000; Mackmin, 1988). Therefore, exporting this experimental study into appraisal practice would entail the collection of reliable data and deployment of commonsense. Notwithstanding the limitations and caveats associated with this study, it is among the limited number of studies that experimented alternative quantitative tools, which, in this case, comprised Excel ${ }^{\circledR}$ Goal Seek and zeros of polynomial equations for the determination of implied rental growth rate of freehold investment properties part-way through rent review epochs. The value of this study is the alternative analytical tools it has availed analysts and investors desiring to ascertain income growth rate required to instantiate specific investment decisions regarding property purchase, retention, and sales.

\section{References}

Adams, A. T., Booth, P. M., \& MacGregor, B. D. (1999). Property Investment Appraisal. British Actuarial Journal, 5, 955-982. https://doi.org/10.1017/S1357321700000763

Baum, A., \& MacGregor, B. (1992). The Initial Yield Revealed: Explicit Valuations and the Future of Property Investment. Journal of Property Valuation $\mathcal{E}$ Investment, 10(4), 709-726. https://doi.org/10.1108/14635789210031334

Baum, A., \& Shi Ming, Y. (1985). The Valuation of Leaseholds: A Review: Part II. Journal of Property Valuation and Investment, 3(3), 230-247. https://doi.org/10.1108/eb007973

Baum, A. E. (2009). Commercial Real Estate Investment: A Strategic Approach. Estates Gazette. https://doi.org/10.4324/9780080963662

Baum, A. E., \& Crosby, N. (2008). Property Investment Appraisal (3rd ed.). Blackwell Publishing Ltd.

Baum, A. E., Mackmin, D., \& Nunnington, N. (2011). The Income Approach to Property Valuation (6th ed.). Elsevier.

Blackledge, M. (2009). Introducing Property Valuation. Taylor \& Francis. https://doi.org/10.4324/9780203876176

Brown, G., \& Matysiak, G. (2000). Real Estate Investment: A Capital Market Approach. Financial TimesPrentice Hall.

Clayton, J., Ling, D. C., \& Naranjo, A. (2009). Commercial Real Estate Valuation: Fundamentals Versus Investor Sentiment. The Journal of Real Estate Finance and Economics, 38, 5-37. https://doi.org/10.1007/s11146-008-9130-6

Crosby, N. (1986). Real Value, Rational Model, D.C.F.: A Reply. Journal of Valuation, 4(1), 16-20. https://doi.org/10.1108/eb007984

Crosby, N. (1996). Valuation and arbitrage: A Comment. Journal of Property Research, 13, 211-220. https://doi.org/10.1080/09599916.1996.9965069

Crosby, N., French, N., \& Ward, C. (1997). Contemporary UK market valuation methods for overrented investment properties: A framework for risk adjustment. Journal of Property Research, 14, 99115. https://doi.org/10.1080/095999197368663

Doppeigieter, J., \& Rode, E. (2002). Capitalization rates and property yields: An analysis of South African commercial property market. Working Paper, International University in Germany, Bruchsal. 
Fraser, W. D. (1993). Principles of Property Investment and Pricing (2nd ed.). Macmillan. https://doi.org/10.1007/978-1-349-13311-6

French, N. (2006a). Value and worth: Scenario analysis. Journal of Property Investment \& Finance, 24(2), 176-179. https:// doi.org/10.1108/14635780610655111

French, N. (2006b). Freehold valuations: The relationship between implicit and explicit DCF methods. Journal of Property Investment \& Finance, 24(1), 87-91. https:// doi.org/10.1108/14635780610642999

Geltner, D., \& de Neufville, R. (2018). Flexibility and Real Estate Valuation under Uncertainty: A Practical Guide for Developers. Wiley-Blackwell. https:// doi.org/10.1002/9781119106470

Geltner, D. M., Miller, N. G., Clayton, J., \& Eichholtz, P. (2010). Commercial Real Estate Analysis and Investments (2nd ed.). Cengage Learning Inc.

Google Finance. (2020). Currency converter. Retrieved 8th August, 2020, from https://www.google.com/search?q=currency+converter\&rlz=1C1LENP_enNL506NL506\&oq=Cur renc\&aqs =chrome.1.69i57j69i59j016.6697j0j8\&sourceid $=$ chrome\&ie=UTF-8

Hargitay, S., \& Yu, S.-M. (1993). Property Investment Decisions: A Quantitative Approach. E \& FN Spon. https://doi.org/10.4324/9780203473849_chapter_1

Hoesli, M., Jani, E., \& Bender, A. (2006). Monte Carlo Simulations for Real Estate Valuation. Journal of Property Investment \& Finance, 24(2), 102-122. https://doi.org/10.1108/14635780610655076

Hoesli, M., \& MacGregor, B. (2000). Property Investment: Principles and Practice of Portfolio Management. Pearson Education Ltd.

Ifediora, B. U. (2005). Valuation Mathematics for Valuers and other Financial and Investment Analysts. Immaculate Publications Ltd.

Isaac, D. (1998). Property Investment. Macmillan. https:// doi.org/10.1007/978-1-349-14468-6

Isaac, D. (2002). Property Valuation Principles. Palgrave.

IVSC. (2003). Guidance Note No. 9 - Discounted Cash Flow (DCF) analysis for market and non-market based valuations. International Valuation Standards Council.

Jones, C., Dunse, N., \& Cutsforth, K. (2015). The changing relationships between government bond yields and capitalisation rates. Evidence from the UK, USA and Australia. Journal of European Real Estate Research, 8(2), 153-171. https://doi.org/10.1108/JERER-05-2015-0023

Li, H. L. (2000). Simple computer applications improve the versatility of discounted cash flow analysis. The Appraisal Journal, 68(1), 86-92.

Mackmin, D. (1988). Implicit v. Explicit Valuation and Investment Analysis. Journal of Property Valuation, 6(2), 148 - 153. https://doi.org/10.1108/eb008025

McGough, T., \& Tsolacos, S. (2001). Do yields reflect property market fundamentals. Real Estate Finance and Investment Research. City University Business School.

McIntosh, A., \& Sykes, S. (1983). Towards a standard property income valuation model: Rationalisation or Stagnation? Journal of Property Valuation and Investment, 1(2), 117-135. https://doi.org/10.1108/eb007927

McIntosh, A., \& Sykes, S. G. (1985). A Guide to Institutional Property Investment. Macmillan. https://doi.org/10.1007/978-1-349-07154-8

Meszek, W. (2013). Property valuation under uncertainty. Simulation vs strategic model. International $\begin{array}{lllll}\text { Journal of Strategic Property Management, } & \text { 17(1), }\end{array}$ https:// doi.org/10.3846/1648715X.2013.782165

Parsons, G. (Ed.). (2003). The Glossary of property terms. Estates Gazette.

RICS. (1997). Commercial investment property valuation methods: An information paper. RICS Business Services Limited.

Sayce, S., Smith, J., Cooper, R., \& Venmore-Rowland, P. (2006). Real Estate Appraisal; Value and Worth. Blackwell Publishers.

Scarrett, D. (2008). Property Valuation: The five methods (2nd ed.). Taylor \& Francis. https://doi.org/10.4324/9780203961810

Sykes, S. G. (1984). Property Valuation: A Rational Model. Journal of Valuation, 2(3), 258-270. https://doi.org/10.1108/eb007956

Udo, G. O. (2003). Model Building in Property Valuation. Institute for Development Studies, University of Nigeria, Enugu Campus.

Wyatt, P. (2007). Property Valuation in an economic context (1st ed.). Blackwell Publishing Ltd. https://doi.org/10.1002/9780470691892

Wyatt, P. (2013). Property Valuation (2nd ed.). Wiley-Blackwell. 